\title{
ANALYSIS OF RAINFALL DATA TO ESTIMATE RAIN CONTRIBUTION TOWARDS CROP WATER REQUIREMENT USING CROPWAT MODEL
}

\author{
Tahir Saeed Laghari, Abdul Khaliq, Syed Hamid Hussain Shah, Shaukat Ali, \\ Haroon Shahzad, Umair Nasir, Researchers \\ University of Agriculture, Faisalabad, Pakistan \\ E-mail: rhs2140@ymail.com
}

\begin{abstract}
A study was carried out to define the analysis of rainfall data in order to estimate its contribution towards crop water requirements to overcome these problems. Rainfall and climatic data was collected from metrological stations, C.P UAF rain gauge (A), (AARI), (B), (CAA), (C) and (WAPDA), (D), Faisalabad of given region and this data was reserved for cross validation. The test station's (A) rainfall data was subjected to double mass curve technique to check its consistency with respect to other rainfall stations (B, $C$ and $D)$ in that area. The results derived by double curve technique were accurate for interested gauge station because there was no any break in curve. Then this consistent data was used to determine effective rainfall. The ETo was established by using penman-monteith method in the course of CROPWAT model and its effect with respect to other parameters like sun shine hour, wind speed, maximum \& minimum temperature and rainfall humidity were determined. It was founded that the reference evapotranspiration ( $E T_{0}$ ) is more during April to September due to increase in temperature and low in remaining months. After that data was placed in the model to acquire crop water requirement and irrigation of illustrative crops (wheat \& maize) from the district. Through which we estimated that $7.5 \%$ rainfall for wheat and $15.5 \%$ rainfall for maize can contribute in actual irrigation per year. Through which we determined that $92.5 \%$ and $84.5 \%$ irrigation is required for wheat and maize crop respectively.
\end{abstract}

\section{KEY WORDS}

Rainfall; Irrigation; Evaporation; Evapotranspiration; Simulation; CROPWAT.

Water is the most common liquid on our planet, essential to all life forms and it is also important for crop need. The need of water is increasing sharply throughout the world which is one of the most burning issues of current time. Fresh water resources are depleting due to global climatic changes, rash use of surface water, and misuse of ground water and fast increasing industrial pollution. World need for food and crop demand is increasing day by day because of rapid increase in population (Bastiaanssen et al., 2000).

Basically $95 \%$ of water is used by the sector of agriculture as compared to other sectors like industrial and house hold in Pakistan. But the efficiency of irrigation system in our country is very low, overall efficiency is $45 \%$ (Bhatti et al., 2009). The water share of agriculture becomes shrunk due to the increasing demand of population growth and industrialization. As a result Pakistan is now in the list of water shortage countries. So because of population growth, Pakistan is going to be exactly water scarce by 2025 (IWMI, 2000).

Per capita availability of water in 1951 was $5,260 \mathrm{~m}^{3}$ and in 2010 the availability was 1038 $\mathrm{m}^{3}$ in Pakistan. This major gap of water demand has directed to severe water scarcity in all divisions. The irrigation system in Pakistan was designed for the cropping intensity of $60-70 \%$ but due to population demand this intensity has increased up to 200\% (WAPDA, 2011). Pakistan is located in a developing country of contradictions and poor rainfall, lying in the extreme North West corner of Pak-Indo sub-continent. At this time, Pakistan is facing shortage of food and water. So, accurate predictions of rainfall and its analysis will help to understand the problems of agriculture, irrigation, floods, and water supplies (Ghaffar and Javid, 2011). 
To overcome these problems and demand for food products we can use the rain, which can be a major part of the water essential for the crops in Pakistan. Pakistan is a country where rain is not only falls in summer season but also in winter season. During the summer monsoon season "July to September" east depression in the Arabian Sea, forming, low altitude rain on the grassland of Pakistan. August is the peak month of the season. "From June to September" approximately $60 \%$ of the annual rainfall over most parts of Pakistan in the summer has received (Adnan and Azmat, 2011). In order to enhance the use of accessible rainfall, crop water requirements for several crops seemed to be sufficient for the purposes of calculating a specific area is determined. Other factors such as recharge and soil moisture content, evapotranspiration, soil type, planting season and harvest all need to be measured which will help us to enhance the productivity (Rugumayo et al., 2003).

Rainfall also determines the potential of any region in term of crops to be produced, farming system to be adopted, the nature and sequence of farming operations to be followed and to achieve higher agricultural productivity as well. Irrigation water requirements are particularly abundant in the works under several surfaces, crop water requirements, crop yield and evapotranspiration as influenced by water accessibility, crop water modeling and irrigation scheduling techniques. Therefore, Double mass curve technique is more reliable for analysis of rainfall data to check the consistency. Then this consistent data and ETo through CROPWAT model can be utilized to estimate the contribution of rainfall towards crop water requirement to determine that how much irrigation is required to enhance the productivity.

Objectives of study:

- Analysis of rainfall data by using double mass curve to check the consistency of rainfall.

- To estimate reference Evapotranspiration $\mathrm{ET}_{0}$ of given region by using CROPWAT model.

- To estimate the \% of rain contribution towards crop water requirement to determine that how much irrigation is required.

\section{MATERIALS AND METHODS}

Procedure. The available rainfall data were collected from four meteorological stations which were of 13 years from (2001-2013) on yearly basis. Then it was analyzed by using the double mass curve technique to check the consistency of rainfall for interested station.

Double mass curve. Double mass curve technique was used to check the consistency of rainfall data of C.P UAF rain gauge (A) by comparing it with other three rain gauges of Ayub Agricultural research institute (AARI), Faisalabad (B), Civil aviation authority (CAA), Faisalabad (C) Water and power development authority (WAPDA), Faisalabad (D). Scatter plot was drawn between cumulative rainfall of interested gauge and mean cumulative rainfall of other surrounding gauges to check the (a) consistency of interested gauge with respect to other gauges, (b) finding out the change in regime occurred, (c) discussing possible causes of deviation, (d) determine the difference for annual average precipitation of 13 years with adjustment of the data.

To check the consistency of rainfall data following methodology was used that explain the whole procedure of double mass curve which is shown below in Figure 1.

From figure we can observe that gauge $X$ data is not consistent. There is change in regime around (year B). This change could be due to gauge re-sitting, human error, gauge measurements and variation in vegetation, trees (Han, 2010).

To remove the error following methodology was used which is given below.

If the earlier period is consistent then, Ratio of Gauge $X$ to other gauges (Year A-Year B) is (Gauge X average / Other Gauges average); Ratio of the in-consistent period (Year C-Year D) is (Gauge $X$ average / Other Gauges average). So, the correction ratio to be made should be $\left(1^{\text {st }}\right.$ value/ $2^{\text {nd }}$ value) is (Consistent period ratio / inconsistent period ratio). 


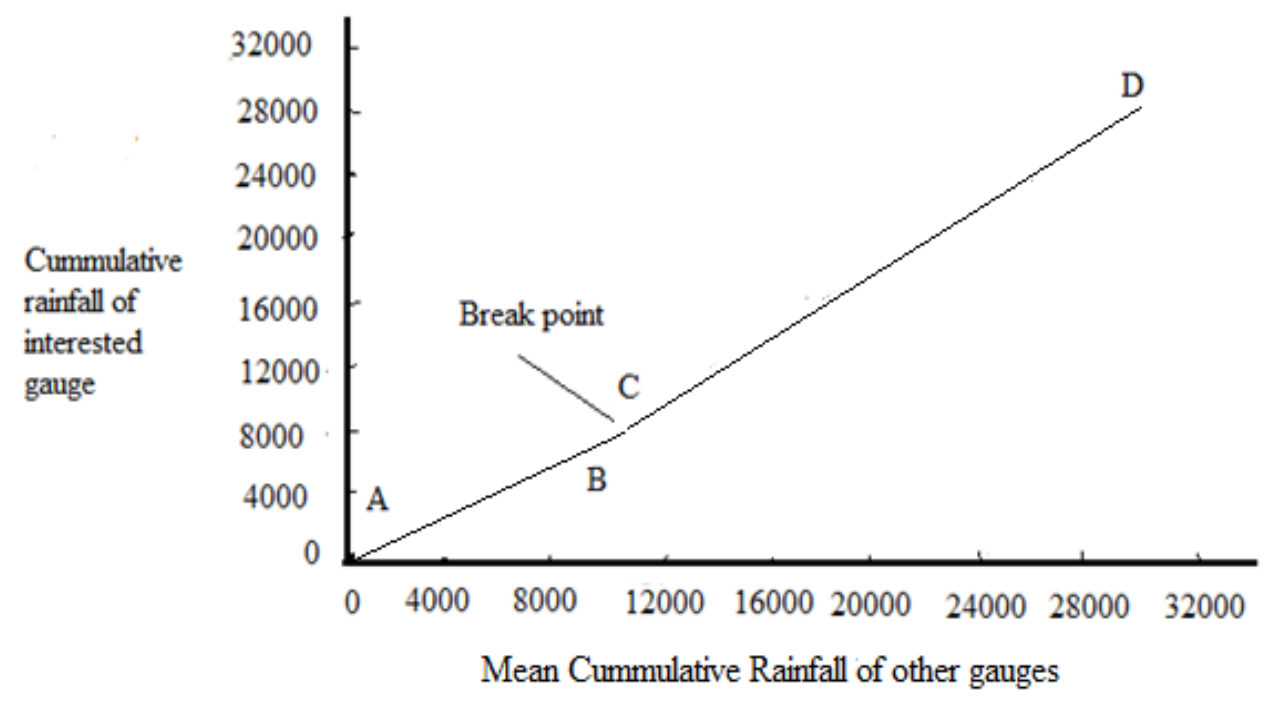

Figure 1 - Double mass curve analysis

That is why all the rainfall values from Year $C$ to Year D are applied with same correction ratio. After checking the consistency of rainfall of interested gauge, this consistent data of interested gauge was used in CROPWAT model to estimate the rainfall contribution towards CWR.

Reference Evapotranspiration $E T_{0}$. The reference evapotranspiration (ETo) represents the potential evaporation of a well-watered grass crop. The water needs of other crops are directly linked to this climatic parameter. Although several methods exist to determine $\mathrm{ET}_{0}$, the PenmanMonteith Method has been recommended as the appropriate combination method to determine $\mathrm{ET}_{\mathrm{o}}$ from climatic data on temperature, humidity, sun shine, wind speed.

For crop water calculations, reference evapotranspiration was determined by using following formula:

$$
E T_{o}=\frac{0.48 \cdot \Delta \cdot(R n-G)+\gamma \cdot \frac{900}{T+273} \cdot U 2 \cdot(e s-e a)}{\Delta+\gamma \cdot(1+0.34 \cdot U 2)},
$$

where, $E T_{o}$ is the reference evapotranspiration; $R_{\mathrm{n}}$ is net radiation at the crop surface; $G$ is the heat flux density; $T$ is the mean daily temperature; $U_{2}$ is the wind speed at $2 \mathrm{~m}$ height; $e_{s}$ is the saturation vapor pressure; $e_{a}$ is the actual vapor pressure; $\Delta$ is the slope vapor pressure curve; $\gamma$ is the psychometric constant.

Effective rainfall. The rainfall contributes to a greater or lesser extent in satisfying CWR, depending on the location. During the rainy season in tropical and some semi-tropical regions, a great part of the crop's water needs are covered by rainfall, while during the dry season, the major supply of water should come from irrigation. How much water is coming from rainfall and how much water should be covered by irrigation is, unfortunately, difficult to predict as rainfall varies greatly from season to season. In order to estimate the rainfall deficit for irrigation water requirements, a statistical analysis needs to be made from long-term rainfall records.

Rainfall Data Collection. The precipitation data required for CROPWAT 8.0 can be daily, decade or monthly rainfall, commonly available from many climatic stations. In addition, substations may be found with single rainfall records. For larger schemes, records of several rainfall stations may be available, allowing an analysis of the spatial variability. To allow a calculation of rainfall probabilities, rainfall records from a range of years (10-20) are to be 
collected. Rainfall data was collected for 13 years from metrological cell installed at given area from 2001-2013 for the determination of dry, normal and wet year values as shown below in Table 1.

Table 1 - Yearly rainfall data from year 2001-2013

\begin{tabular}{|c|c|c|c|c|c|c|c|c|c|c|c|c|c|}
\hline Years & Jan & Feb & Mar & Apr & May & Jun & Jul & Aug & Sep & Oct & Nov & Dec & Total \\
\hline 2001 & 2 & 0 & 5 & 26 & 8.45 & 140.5 & 126 & 38.8 & 8.5 & 2.25 & 1.5 & 2 & 361 \\
\hline 2002 & 0 & 2 & 5.25 & 5.5 & 16 & 63 & 24.6 & 66.2 & 26 & 1.5 & 0.2 & 4.7 & 215 \\
\hline 2003 & 4.4 & 80.2 & 36.5 & 1.6 & 11 & 15.6 & 133.7 & 143.6 & 54 & 0 & 10 & 10 & 500.6 \\
\hline 2004 & 18 & 6 & 0 & 26.6 & 1.8 & 98.1 & 14.8 & 86.8 & 34.6 & 8 & 9 & 2 & 305.7 \\
\hline 2005 & 32.8 & 35.1 & 48.6 & 10.8 & 18.4 & 62.5 & 88 & 51.6 & 84.6 & 10 & 0 & 0 & 442.4 \\
\hline 2006 & 8.2 & 14.6 & 37 & 0 & 24 & 36 & 36 & 79.2 & 76.2 & 7.4 & 12.8 & 46.2 & 377.6 \\
\hline 2007 & 0 & 55.9 & 41.3 & 0 & 16.1 & 29.9 & 149.7 & 19.5 & 12.2 & 0 & 0 & 6 & 330.6 \\
\hline 2008 & 46.6 & 6.8 & 0 & 16 & 75.5 & 41.7 & 81.6 & 204.5 & 28.8 & 0 & 0 & 14.6 & 516.1 \\
\hline 2009 & 13.5 & 18.2 & 14 & 22.9 & 9.1 & 9.6 & 43.5 & 116 & 20.6 & 17.5 & 0.7 & 0 & 285.6 \\
\hline 2010 & 0.8 & 11.9 & 8.8 & 1.3 & 11.2 & 1 & 277.8 & 226.6 & 86.5 & 0 & 0 & 1 & 626.9 \\
\hline 2011 & 0 & 20.6 & 6.8 & 20.9 & 18.6 & 78.3 & 118.1 & 92.6 & 155.1 & 0.4 & 0 & 0 & 511.4 \\
\hline 2012 & 3.8 & 8 & 1.5 & 10.5 & 0 & 23.6 & 45.4 & 38.5 & 163.7 & 11.5 & 0 & 17.2 & 323.7 \\
\hline 2013 & 1.5 & 55 & 1.27 & 21.6 & 4.6 & 67.5 & 4.6 & 114.8 & 3.3 & 0 & 0.5 & 0 & 274.7 \\
\hline Avg. & 10.12 & 24.18 & 15.85 & 12.59 & 16.52 & 51.33 & 87.98 & 98.36 & 58.01 & 4.50 & 2.67 & 7.98 & 390.1 \\
\hline
\end{tabular}

Rainfall Data Processing. For programming of irrigation water supply and management, rainfall data of normal, wet and dry years are used. An estimate of the respective rainfall data can be obtained by computing and plotting probabilities from the rainfall records to determine dry, normal and wet year values (Abdalla et al., 2010). The different steps involved are:

1. Tabulate yearly rainfall totals for a given period;

2. Arrange data in descending order of magnitude.

Table 2 - Yearly rainfall totals from year 2001-2013

\begin{tabular}{|c|c|c|c|c|c|c|c|c|c|c|c|c|c|}
\hline Years & 2001 & 2002 & 2003 & 2004 & 2005 & 2006 & 2007 & 2008 & 2009 & 2010 & 2011 & 2012 & 2013 \\
\hline $\begin{array}{c}\text { Rainfall, } \\
\text { mm }\end{array}$ & 361 & 215 & 500.6 & 305.6 & 442.4 & 377.6 & 330.6 & 516.1 & 285.6 & 626.9 & 511.4 & 323.7 & 274.7 \\
\hline Rank No. & 7 & 13 & 4 & 10 & 5 & 6 & 8 & 2 & 11 & 1 & 3 & 9 & 12 \\
\hline
\end{tabular}

1. Tabulate plotting position according to $\mathrm{Fa}=100{ }^{*} \mathrm{~m} /(\mathrm{N}+1)$, where $\mathrm{N}=$ number of records; $\mathrm{m}=$ rank number; $\mathrm{Fa}=$ plotting position.

2. Plot values on log-normal scale and obtain the logarithmic regression equation. Calculate year values at 20,50 and $80 \%$ probability.

Effective Rainfall Method. In general, the efficiency of rainfall will decrease with increasing rainfall. For most rainfall values below/above the $100 \mathrm{~mm} / \mathrm{month}$, the efficiency will be approximately $80-90 \%$. Unless more detailed information is available for local conditions, it was suggested to select the Option "USDA Soil Conservation Service". For this purpose following formula was used:

$$
\begin{array}{lll}
P_{\text {eff }}=\frac{\text { Ptot }(125-0.2 P \text { tot })}{125} & \text { for } & P<250 \mathrm{~mm} \\
P_{\text {eff }}=125+0.1 P_{\text {tot }} & \text { for } & P>250 \mathrm{~mm}
\end{array}
$$

Crop Data Information. CROPWAT 8.0 has crop data for several common crops taken from selected FAO publications. However, the most reliable general crop data for Wheat and Maize was selected from local agricultural research stations, pars Faisalabad. 
Data required differ in case of non-rice or a rice crop. In case of non-rice crop, the following information is necessary, Crop name, Planting date, Crop coefficient (Kc), Stages length, Rooting depth, Critical depletion fraction (p), Yield response factor (Ky).

Crop Water Requirement Calculations. Secondary data required for computation of crop consumptive use that was determined by CROPWAT model is $\mathrm{ET}_{0}\left(\mathrm{~mm}_{\text {.day }}{ }^{-1}\right)$ for the study area were collected from Department of Crop Physiology University of Agriculture Faisalabad. Crop water requirement $(C W R)$ was estimated using the appropriate crop coefficient $\left(K_{c}\right)$ (Naheed and Ghulam, 2013).

$$
\begin{aligned}
& \mathrm{ET}_{\mathrm{c}}=\mathrm{K}_{\mathrm{c}} \cdot \mathrm{ET}_{\mathrm{o}} \text { or } \mathrm{CWR}=\mathrm{K}_{\mathrm{c}} \cdot \mathrm{ET}_{\mathrm{o}} \\
& \mathrm{ET}_{\mathrm{c}}=\mathrm{CWR}=\text { Actual crop water requirement } \\
& \mathrm{K}_{\mathrm{c}}=\text { Crop coefficient } \\
& \mathrm{ET}_{\mathrm{o}}=\text { Reference evapotranspiration }
\end{aligned}
$$

From $\mathrm{FAO}$ guidelines $\mathrm{K}_{\mathrm{c}}$ values were selected for each of the main crops and their water requirements were calculated.

Irrigation Water requirement. When the amount of water required for the crop is determined from the modeling software by neglecting the rainfall applied water. Then the remaining water required for the crop can be applied to the crop according to designed procedure. So crop should be irrigated when required and how much required. Keeping in view the sowing should be after the rain saving first irrigation as well as by modeling the timings can be calculated formulating schedule for the irrigation supply according to demand.

\section{RESULTS AND DISCUSSION}

Rainfall consistency using Double Mass Curve. The lower tables (Table No.4.1 and 4.2) presents the mean and cumulative mean rainfalls for stations (A, B, C and D) for years 2001 to 2013, respectively. Then to check the consistency of data for station $A$ with respect to other stations $B, C$ and $D$ we used double mass curve technique using correlation. Their relative curve has been shown in Figure 4.1 that shows a strong correlation between the cumulative means of other stations and the cumulative rainfall of interested gauge. As there is no break throughout the thirteen years period that is why there is no need to calculate a correction factor to make the data consistent because strong correlation showing consistent data. Same technique can also be used to check the consistency of rainfall for other stations of the area as per requirement. This consistent data is used for predictions and to finding out the percentage contribution of rainfall towards crop water requirement.

Table 3 - Non-cumulative rainfall with mean for stations (A, B, C and D)

\begin{tabular}{|c|c|c|c|c|c|}
\hline Years & A & B & C & D & Mean \\
\hline 2001 & 361 & 372 & 373.7 & 371.9 & 370 \\
\hline 2002 & 215 & 270.9 & 271 & 274.1 & 257.7 \\
\hline 2003 & 500.6 & 408.9 & 408.8 & 379.2 & 424.4 \\
\hline 2004 & 305.7 & 376.6 & 374.4 & 376.6 & 358.3 \\
\hline 2005 & 442.4 & 517.8 & 463.8 & 518.2 & 485.6 \\
\hline 2006 & 377.6 & 353.7 & 403.9 & 444.4 & 394.9 \\
\hline 2007 & 330.6 & 345.6 & 323.4 & 351.7 & 337.8 \\
\hline 2008 & 516.1 & 656.8 & 644.8 & 637.4 & 613.8 \\
\hline 2009 & 285.6 & 378.2 & 376.1 & 372.7 & 353.2 \\
\hline 2010 & 626.9 & 544 & 544.5 & 544.7 & 565 \\
\hline 2011 & 511.4 & 543.4 & 512 & 544.9 & 527.9 \\
\hline 2012 & 323.7 & 359.6 & 363 & 366.1 & 353.1 \\
\hline 2013 & 274.7 & 379.2 & 375.1 & 378.1 & 351.8 \\
\hline
\end{tabular}


Table 4 - Cumulative rainfall with mean for stations (A, B, C and D)

\begin{tabular}{|c|c|c|c|c|c|}
\hline Years & $\mathrm{A}$ & $\mathrm{B}$ & $\mathrm{C}$ & $\mathrm{D}$ & Cumulative mean \\
\hline & 0 & 0 & 0 & 0 & 370 \\
\hline 2001 & 361 & 372 & 373.7 & 371.9 & 627 \\
\hline 2002 & 576 & 642.9 & 644.5 & 646 & 1052 \\
\hline 2003 & 1077 & 1051.8 & 1053.3 & 1025.2 & 1410 \\
\hline 2004 & 1382 & 1428.4 & 1427.7 & 1401.8 & 1896 \\
\hline 2005 & 1825 & 1946.2 & 1891.5 & 1920 & 2290 \\
\hline 2006 & 2202 & 2299.9 & 2295.4 & 2364.4 & 2628 \\
\hline 2007 & 2533 & 2645.5 & 2618.8 & 2716.1 & 3242 \\
\hline 2008 & 3049 & 3302.3 & 3263.6 & 3353.5 & 3595 \\
\hline 2009 & 3335 & 3680.5 & 3639.7 & 3726.2 & 4160 \\
\hline 2010 & 3961 & 4224.5 & 4184.2 & 4270.9 & 4688 \\
\hline 2011 & 4473 & 4767.9 & 4696.2 & 4815.8 & 5 \\
\hline 2012 & 4797 & 5127.5 & 5059.2 & 5181.9 & 5 \\
\hline 2013 & 5071 & 5506.7 & 5434.3 & 5560 & \\
\hline
\end{tabular}

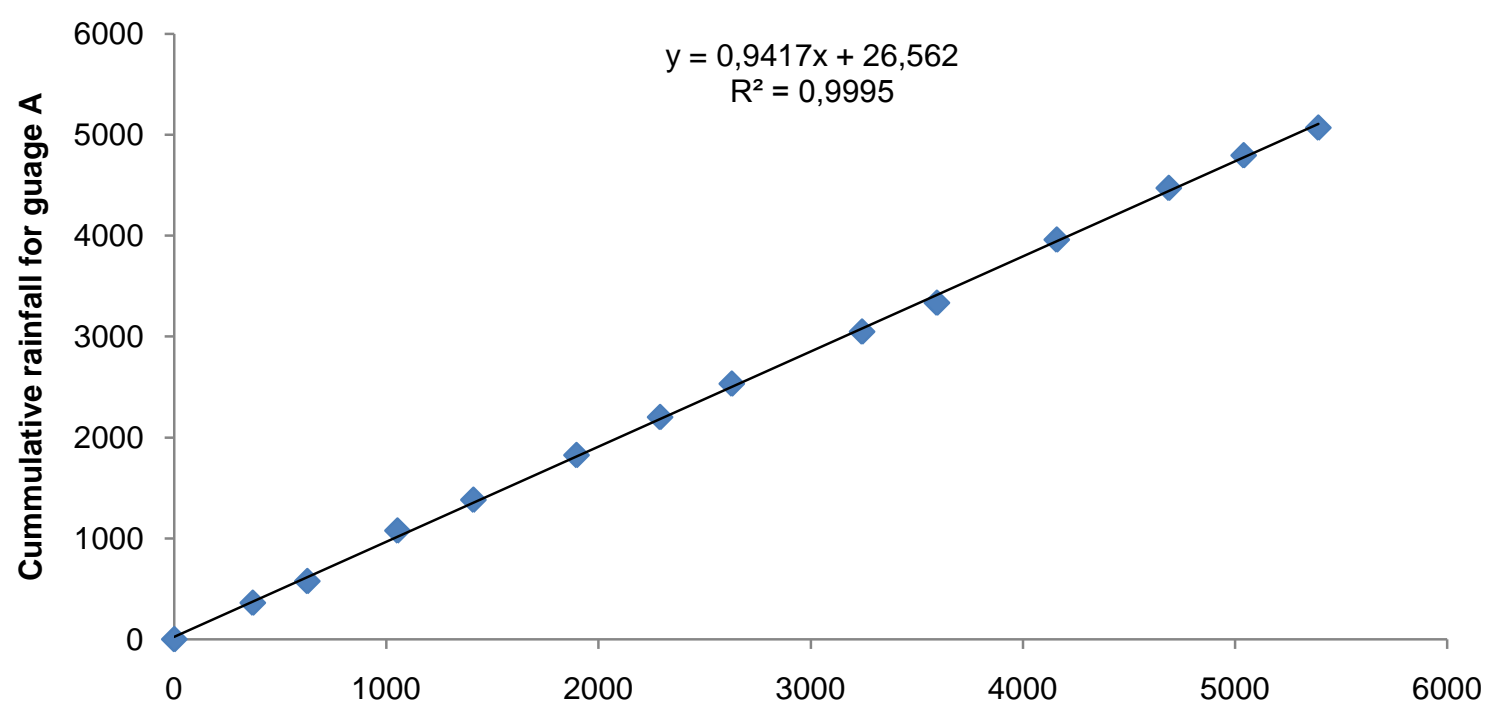

Mean cummulative rainfall for other guages

Figure 2 - Double mass curve analysis for station A with respect to other rainfall stations

Reference evapotranspiration $E T_{0}$ from years (2001-2013). The $E T_{0}$ was low in Jan to March (1.52 to $3.73 \mathrm{~mm} \mathrm{day}^{-1}$ ) due to less radiation intensity in this area, then enhanced during April to September (5.57 and $\left.5.05 \mathrm{~mm} \mathrm{day}^{-1}\right)$ and reaching maximum value $\left(7.45 \mathrm{~mm} \mathrm{day}^{-1}\right)$ at June and $\mathrm{ET}_{\text {o }}$ was declined during July to December (3.66 to $1.78 \mathrm{~mm}$ day $^{-1}$ ) due to again decrease in the radiation intensity and the atmospheric temperature as shown in figure given below.

Figure show the decrease in $\mathrm{ET}_{0}$ during January to March is mainly attributed to low temperature while during April to September period highest of the temperatures range prevails that resulted in increased $\mathrm{ET}_{0}$. In after months there is again decrease in temperature hence there is also decrease in $\mathrm{ET}_{0}$. 


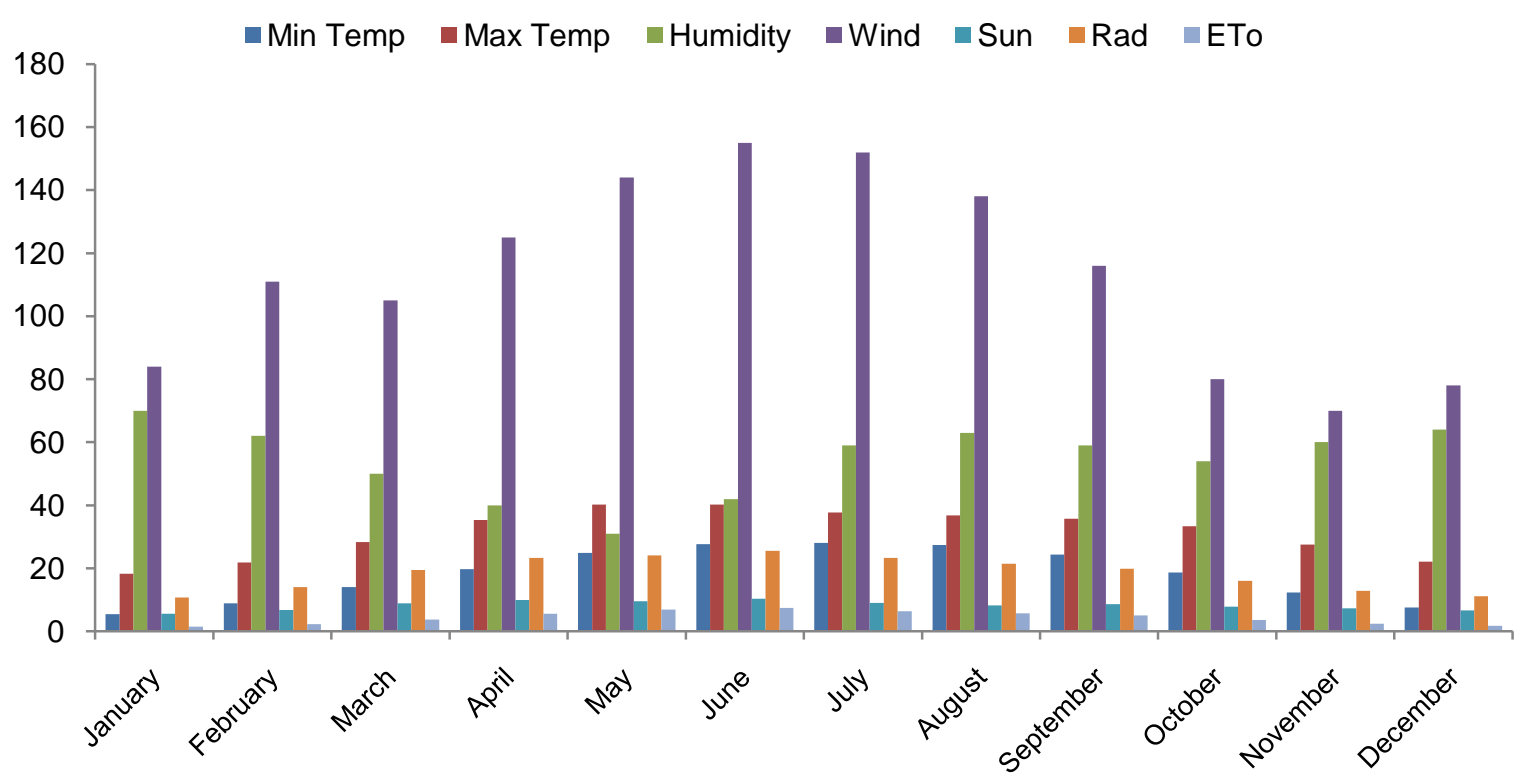

The difference in $\mathrm{ET}_{0}$ along with radiation intensity is also accredited to combined impacts of temperature, sunshine hours, wind speed and humidity. Figure show the direct relationship between ETo and temperature, sunshine hours, wind speed, respectively and inversely proportional to humidity.

Rainfall data processing to calculate dry, normal and wet year rainfall values from 20012013. On the basis of the probability exceedance (figure) in log-normal scale years can be classified into three categories: Dry years; Normal years; Wet years.

Dry years are those which lie on $80 \%$ exceedance with rainfall value of $280 \mathrm{~mm}$ while the normal years are those which lie on $50 \%$ exceedance with rainfall value of $360 \mathrm{~mm}$ and wet years are those which lie on $20 \%$ exceedance with $520 \mathrm{~mm}$ rainfall values, respectively.

Table 5 - Plotting position values for (2001-2013)

\begin{tabular}{|c|c|c|c|c|c|c|c|c|c|c|c|c|c|}
\hline Rank No. & 1 & 2 & 3 & 4 & 5 & 6 & 7 & 8 & 9 & 10 & 11 & 12 & 13 \\
\hline Rainfall, $\mathrm{mm}$ & 625.9 & 516.1 & 511.4 & 500.6 & 442.4 & 377.6 & 361 & 330.6 & 323.7 & 305.6 & 285.6 & 274.7 & 215 \\
\hline Fa, \% & 7 & 14 & 21 & 29 & 36 & 43 & 50 & 57 & 64 & 71 & 79 & 86 & 93 \\
\hline
\end{tabular}

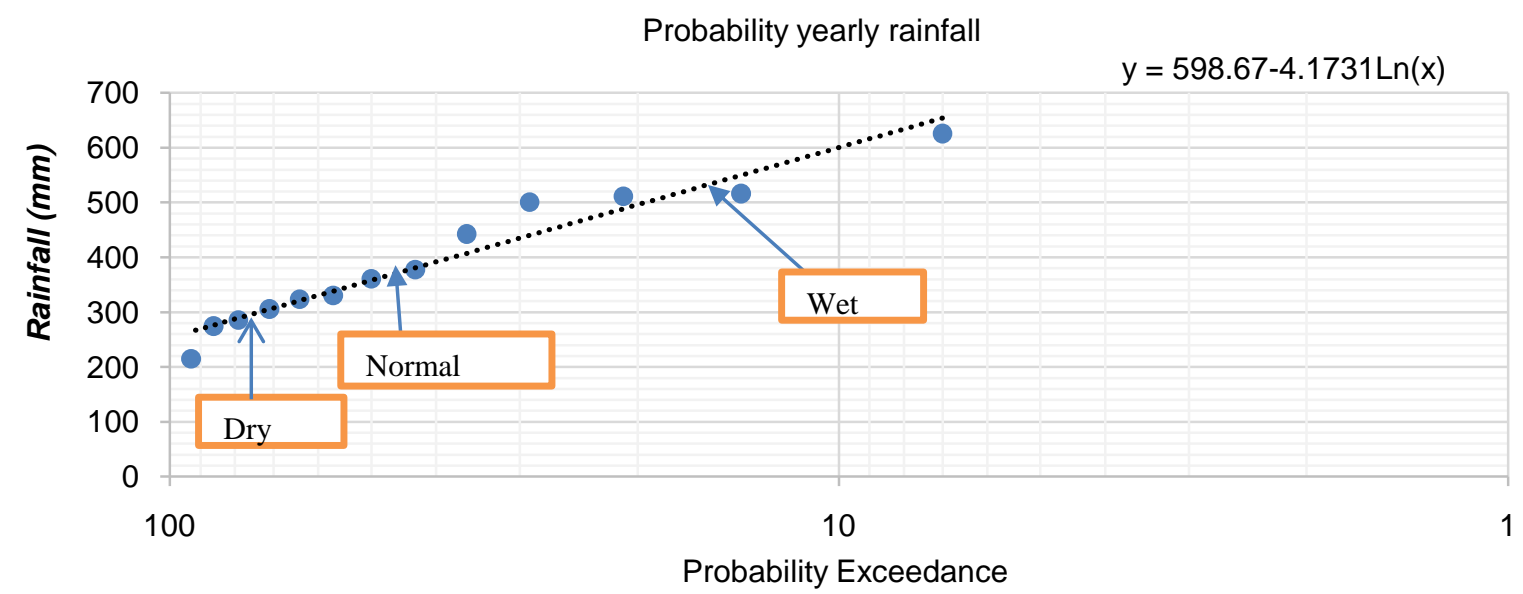

Figure 3 - Dependable Rain at 20, 50 and $80 \%$ exceedance 
Percent rainfall contribution and artificial irrigation for wheat and maize water requirement. Rain is one of the major contributors to meet the irrigation requirements of the crop. But due to negligence as well as unawareness about the use most of the rainfall water is effectively up taken by crop plants. For this purpose this model helps us to predict the requirement of water with telling much of water can be saved as is provided by the rain. Sequential contributions of rainfall for maize and wheat crops are presented in tables (4.1 and 4.2) for 13 years from (20012013).

It can be observed that there is contribution of $4.5,2.5,12.08,9.1,13.06,9.83,3.14$, $10.69,11.41,32.6,36.9,48.6$ and $6.5 \%$ in irrigation requirement of maize from 2001 to 2013 saving much amount of water which is a scarce resource.

For wheat crop rainfall contributes about 2.3, 2.5, 13.36, 2.09, 17.19, 6.14, 10.9, 6, 16.55, $4.9,5.3,4.7$ and $6.57 \%$ of the irrigation requirement for respective years from 2001-2013.

Table 6 - Rainfall contribution in irrigation requirement of maize from 2001 to 2013

\begin{tabular}{|c|c|c|c|c|c|c|c|}
\hline Year & $\begin{array}{c}\text { Total gross } \\
\text { Irrigation } \\
(\mathrm{mm})\end{array}$ & $\begin{array}{c}\text { Total } \\
\text { Rainfall } \\
(\mathrm{mm})\end{array}$ & $\begin{array}{c}\text { Effective } \\
\text { Rainfall } \\
(\mathrm{mm})\end{array}$ & $\begin{array}{c}\text { Rain } \\
\text { Efficiency } \\
(\%)\end{array}$ & $\begin{array}{c}\text { Actual Irrigation } \\
\text { Requirement } \\
(\mathrm{mm})\end{array}$ & $\begin{array}{c}\text { Rainfall } \\
\text { Contribution } \\
(\%)\end{array}$ & $\begin{array}{c}\text { Irrigation } \\
\text { Contribution } \\
(\%)\end{array}$ \\
\hline 2001 & 483.1 & 144.6 & 15.2 & 10.5 & 336.3 & 4.5 & 95.5 \\
\hline 2002 & 611.6 & 116.8 & 11 & 9.4 & 431 & 2.5 & 97.5 \\
\hline 2003 & 6433.6 & 317.8 & 52.7 & 16.6 & 436.2 & 12.08 & 88.92 \\
\hline 2004 & 724.9 & 144.2 & 45.1 & 31.3 & 494.4 & 9.1 & 90.9 \\
\hline 2005 & 634.3 & 206 & 56.9 & 27.6 & 435.4 & 13.06 & 86.94 \\
\hline 2006 & 549.5 & 191.4 & 38 & 19.9 & 386.4 & 9.83 & 90.17 \\
\hline 2007 & 685.8 & 181.4 & 16.2 & 8.9 & 473.9 & 3.41 & 96.59 \\
\hline 2008 & 558.3 & 314.9 & 41.5 & 13.2 & 388.2 & 10.69 & 89.31 \\
\hline 2009 & 598.4 & 192.1 & 47.1 & 24.5 & 412.7 & 11.41 & 88.59 \\
\hline 2010 & 466.8 & 590.9 & 95.2 & 16.1 & 292.2 & 32.6 & 67.4 \\
\hline 2011 & 367.5 & 354.6 & 89.8 & 25.3 & 243.6 & 36.9 & 63.1 \\
\hline 2012 & 465.7 & 247.6 & 123.3 & 49.8 & 253.8 & 48.6 & 51.4 \\
\hline 2013 & 566.2 & 122.9 & 25.9 & 21.1 & 396.6 & 6.5 & 93.5 \\
\hline
\end{tabular}

Table 7 - Rainfall contribution in irrigation requirement of wheat from 2001 to 2013

\begin{tabular}{|c|c|c|c|c|c|c|c|}
\hline Year & $\begin{array}{c}\text { Total gross } \\
\text { Irrigation } \\
(\mathrm{mm})\end{array}$ & $\begin{array}{c}\text { Total } \\
\text { Rainfall } \\
(\mathrm{mm})\end{array}$ & $\begin{array}{c}\text { Effective } \\
\text { Rainfall } \\
(\mathrm{mm})\end{array}$ & $\begin{array}{c}\text { Rain } \\
\text { Efficiency } \\
(\%)\end{array}$ & $\begin{array}{c}\text { Actual Irrigation } \\
\text { Requirement } \\
(\mathrm{mm})\end{array}$ & $\begin{array}{c}\text { Rainfall } \\
\text { Contribution } \\
(\%)\end{array}$ & $\begin{array}{c}\text { Irrigation } \\
\text { Contribution } \\
(\%)\end{array}$ \\
\hline 2001 & 749.5 & 40.3 & 12.1 & 30 & 521.7 & 2.3 & 97.7 \\
\hline 2002 & 696.3 & 17.5 & 12.2 & 69.7 & 488.9 & 2.5 & 97.5 \\
\hline 2003 & 833.5 & 132.7 & 72.6 & 54.7 & 543.1 & 13.36 & 86.64 \\
\hline 2004 & 958.1 & 30.4 & 14 & 46.1 & 669.3 & 2.09 & 97.91 \\
\hline 2005 & 732.6 & 145.7 & 83.2 & 57.1 & 484 & 17.19 & 82.81 \\
\hline 2006 & 748.6 & 127.8 & 32.1 & 25.1 & 522.3 & 6.14 & 93.86 \\
\hline 2007 & 618.7 & 119 & 45.4 & 38.1 & 416.2 & 10.9 & 89.1 \\
\hline 2008 & 825.9 & 96.9 & 34.5 & 35.6 & 575.3 & 6 & 94 \\
\hline 2009 & 616 & 77.7 & 68.7 & 88.4 & 415.1 & 16.55 & 84.45 \\
\hline 2010 & 769.6 & 35 & 25.9 & 74 & 527.1 & 4.9 & 95.1 \\
\hline 2011 & 743.1 & 52.3 & 27.6 & 52.8 & 514.8 & 5.3 & 94.7 \\
\hline 2012 & 742.1 & 51.2 & 24.3 & 48.1 & 512.1 & 4.7 & 95.3 \\
\hline 2013 & 722.2 & 84 & 32.3 & 38.4 & 491.1 & 6.57 & 93.43 \\
\hline
\end{tabular}

Keeping in view the above all years' rainfall data the average contribution of rainfall for irrigation of wheat and maize crops in that area per year is counted to be $7.5 \%$ and $15.5 \%$ respectively. That is why we can save this water with applying only $92.5 \%$ water to wheat crop and $84.5 \%$ water to maize crop respectively, as their requirement per year instead of applying $100 \%$ irrigation water. 
Keeping in view the prevailing conditions in a year and the previous year's one can predict how much will be the rains the coming season and can manage the irrigation requirements for the crop.

\section{ACKNOWLEDGEMENTS}

We are thankful to Crop Physiology Dept. UAF, Ayub Agricultural research institute (AARI), Faisalabad, Civil aviation authority (CAA), Faisalabad and Water and power development authority (WAPDA), Faisalabad for their support in collection of the 13 years rainfall data.

\section{REFERENCES}

1. Abdalla, N.M., Zhang, X., Adam, I. and Gamareldawla, H. 2010. Estimating Reference Evapotranspiration Using CROPWAT model at Guixi Jiangxi Province, Journal of Water Resources and Hydraulic Engineering.

2. Adnan, S. and Azmat, H.K. 2011. Effective Rainfall for Irrigated Agriculture Plains of Pakistan. Pakistan Journal of Meteorology: Vol. 6, Issue 11.

3. Bastiaanssen, W.G.M., David, J.M. and lan, W.M. 2000. Remote sensing for irrigated agriculture: examples from research and possible applications, Agriculture Water Management 46:137-155.

4. Bhatti, A.M., Pongsak, S. and Seigo, N. 2009. Agriculture water demand management in Pakistan: a review and perspective. Society for Social Management Systems 9(172):1-7.

5. Ghaffar, A and Javid, M. 2011. Impact of global warming on monsoon variability in Pakistan, The Journal of Animal \& Plant Sciences, 21(1): 107-110.

6. Han, D. 2010. Concise Hydrology $1^{\text {st }}$ edition, www.bookboon.com, ISBN: 978-87-7681-536-3. $P: 17-22$.

7. IWMI. 2000. World water supply and demand 1995 to 2025 draft, International Water Management Institute: Colombo, Sri Lanka

8. Rugumayo, A.I., Kiiza, N. and Shima, J. 2003. Rainfall reliability for crop production, a case study in UGANDA.

9. WAPDA. 2011. Hydro Potential in Pakistan, Pakistan Water and Power Development Authority (www.wapda.gov.pk). 